\title{
CHARACTERISTICS OF ZOOPLANKTON FUNCTIONAL GROUPS AND THEIR ENVIRONMENTAL FACTORS IN THE HARBIN SECTION OF THE SONGHUA RIVER, CHINA
}

\author{
ZhAO, F. $.^{12^{*}}-$ YU, H. X. ${ }^{*}-$ MA, C. X. ${ }^{1 *}-$ SUN, X. ${ }^{1}-$ LIU, D. ${ }^{1}-$ ShANG, L. Y. ${ }^{1}-$ LIU, J. M. ${ }^{1}$ \\ LI, X. Y. ${ }^{1}-$ LI, S. ${ }^{1}-$ LI, X. C. ${ }^{1}-$ YU, T. Y. ${ }^{1}-$ SHABANI, I. E. ${ }^{1}-$ WANG, Y. Z. ${ }^{2}-$ SU, L. J. ${ }^{2}-$ \\ ZHANG, L. M. ${ }^{2}-\mathrm{MU}, \mathrm{Y} . \mathrm{Y}^{2}{ }^{2}-\mathrm{XIAO}, \mathrm{L}^{2}{ }^{2}-$ TIAN, Z. ${ }^{2}-\mathrm{PAN}, \mathrm{C}^{2}-\mathrm{SUN}, \mathrm{B}^{2}-\mathrm{PAN}^{2}$ H. F. ${ }^{3}-$ \\ SHANG, G. Y. Q. ${ }^{4}-$ CHAI, F. Y. ${ }^{5}-$ MENG, Y. ${ }^{6}$ \\ ${ }^{1}$ Department of Ecology, College of Wildlife and Protected Area, Northeast Forestry University, \\ Harbin 150040, China \\ ${ }^{2}$ The Water Ecology Laboratory, Hydrology and Water Resources Survey Station in Harbin, \\ Harbin 150028, China \\ ${ }^{3}$ Greater Khingan Ling Survey, Planning and Design Institute, National Forestry and Grassland \\ Administration, Jagdaqi 16500, China \\ ${ }^{4}$ B1 West Building, WF CENTRAL, Building 1, 269 Wangfujing Street, Dongcheng District, \\ Beijing 100006, China \\ ${ }^{5}$ School of Management, Heilongjiang University of Science and Technology, Harbin 150020, \\ China \\ ${ }^{6}$ Department of Wetland Ecology and Environment, Northeast Institude of Geography and \\ Agroecology, Chinese Academy of Sciences, Changchun, China \\ *Corresponding authors \\ e-mail:iamzhaofei@foxmail.com; phone: +86-150-4586-2146 (Zhao, F.) \\ e-mail: china.yhx@163.com; phone: +86-131-0096-0911 (Yu, H.X.) \\ e-mail: mch007@vip.163.com; phone: +86-180-0366-8291 (Ma, C.X.)
}

(Received $23^{\text {rd }}$ Jul 2020; accepted $17^{\text {th }}$ Sep 2020)

\begin{abstract}
In order to determine the spatial and temporal relationship between environmental factors and zooplankton functional groups in the Harbin section of the Songhua River, China, we collected water samples of zooplankton separately at 6 sampling sites in spring, summer and autumn in 2012. In this study, a total of 26 species of zooplankton were collected from Harbin section of the Songhua River, belonging to 6 functional groups. Both environmental factors and the biomass of zooplankton functional groups exhibited spatial and seasonal differences. Water temperature (WT), chemical oxygen demand (CODcr), total phosphorus (TP), nitrate $\left(\mathrm{NO}^{3-}\right)$ and dissolved iron $\left(\mathrm{Fe}^{3+}\right)$ were significantly higher in summer. On the contrary, $\mathrm{pH}$, dissolved oxygen (DO) and 5 days' biochemical oxygen demand $\left(\mathrm{BOD}_{5}\right)$ were significantly lower in summer. The biomass of zooplankton functional groups was higher in spring and lower in summer. According to the results of Redundancy analysis (RDA): water temperature (WT), dissolved oxygen (DO), pH, chemical oxygen demand (CODcr), 5 days biochemical oxygen demand $\left(\mathrm{BOD}_{5}\right)$, total phosphorus $(\mathrm{TP}), \mathrm{N}$ : $\mathrm{P}$ ratio $(\mathrm{N}: \mathrm{P})$ and dissolved iron $\left(\mathrm{Fe}^{3+}\right)$ were the major factors influencing zooplankton functions.
\end{abstract}

Keywords: functional traits, biomass, environmental factors, Songhua River, Redundancy analysis (RDA) 


\section{Introduction}

Zooplankton functional groups play an important ecological role in aquatic environments, such as the energy and material flow links between phytoplankton from small primary producers and fish of larger secondary consumers. In the meantime, these aquatic organisms perform important functions in the biogeochemical cycle by participating in alternative food webs, such as consumers (e.g., microbial and detritus) (Leoni, 2016; Lira et al., 2018). Zooplankton has become increasingly important in biological monitoring projects because of their rapid response to natural and anthropogenic environmental changes (Vieira et al., 2011; Mano and Tanaka, 2016). Traditional systems divided zooplankton into different communities to reflect water quality condition and biodiversity, but it had trouble reflecting the ecological function of aquatic organisms (Hood et al., 2006). Therefore, in order to study the functional role of zooplankton in the ecosystem, ecologists proposed the concept of functional groups. The study of functional groups, is more directly reflected the interaction between environmental factors and aquatic communities, and is also helpful in understanding aquatic ecosystem and biodiversity (Hoeinghaus et al., 2007). The species characteristics of the functional groups were more closely related to the environment, which can better understand the indicative role of zooplankton in environmental changes (Le et al., 2005).

Functional traits are the characteristics of the interaction between an organisms and their ecosystem (Tilman, 2001; Petchey and Gaston, 2002). Including taxonomic and functional groups analysis may increase the evaluation of biological responses to environmental changes (Petchey and Gaston, 2006; Cianciaruso et al., 2009). In zooplankton communities, Litchman et al. (2013) pointed out that the functional groups of organisms may include three ecological functions of feeding, growth/reproduction and survival. According to Obertegger et al. (2011) and Rizo et al. (2017), zooplankton functional groups related to raptorial or microphage organisms in zooplankton feeding guilds association were used for assessment. At present, functional groups studies have been used more and more in many fields of ecology. For instance, ecological succession (Raevel et al., 2012), meta-community (Gianuca et al., 2018) and beta diversity (Pool et al., 2014).

The zooplankton was classified into different functional groups, which can effectively simplify the food webs, and simulate the ecological processes of zooplankton communities comprehensively and accurately. However, the designation and measurement of zooplankton functional groups is still a difficult task, especially for small organisms (Martiny et al., 2013). In order to study the plankton in Sanjiang plain in China's freshwater ecosystem, according to the size, feeding habits and nutrition level (Zhao, 2005; Benedetti et al., 2018), zooplankton was divided into ten functional groups: protozoa filter feeders (PF), protozoa carnivore (PC), rotifer filter feeders (RF), rotifer carnivore (RC), small copepods and cladocerans filter feeders (SCF), small copepods and cladocerans carnivore (SCC), middle copepods and cladocerans filter feeders (MCF), middle copepods and cladocerans carnivore (MCC), large copepods and cladocerans filter feeders (LCF) and large copepods and cladocerans carnivore (LCC).

Phytoplankton composition and structure have been researched by different scientists in the Songhua River in China (Bao et al., 1987; Wei, 2018). These authors have reported: (i) dominance of Diatoms and Chlorophyta and (ii) the most influential environmental parameters of $\mathrm{pH}$, water temperature, specific conductance and total phosphorus in the Harbin section of the Songhua River, China. However, despite 
phytoplankton and zooplankton forms essential component of aquatic foodweb, no studies about zooplankton community structure or functional groups has been conducted in the Songhua River, China. Songhua River is one of the seven major rivers in China, which is of great significance. The main objectives of this study are: (i) to assess the seasonal variation of zooplankton functional groups and their biomass and (ii) determine the environmental variables influencing the biomass of the seasonal variation of zooplankton functional groups in the Harbin section of the Songhua River. The results in this research are important for management of the Songhua River and other aquatic systems with similar characteristics in our nation.

\section{Materials and methods}

\section{Research area}

The study was conducted in the Harbin section of the Songhua River located at $45^{\circ} \mathrm{N}$ $126^{\circ} \mathrm{W}$ in Heilongjiang Province, Northeast China (Fig. 1, Table 1). Songhua River, is one of the seven major rivers in China. Harbin section of the Songhua River runs from Sanjiazi Village to Dadingzi Mountain with a total length of $66 \mathrm{~km}$ (Li et al., 2014). The annual precipitation was $300-1200 \mathrm{~mm}$, and the overall trend was decreasing from southeast to northwest. The average annual runoff was $632.0 \times 10^{8} \mathrm{~m}^{3}(1955-2010)$, and the average annual sediment transport was $1,259 \times 10^{4} \mathrm{t}$ (1955-2010) (Songliao Water Resources Commission, 2012).

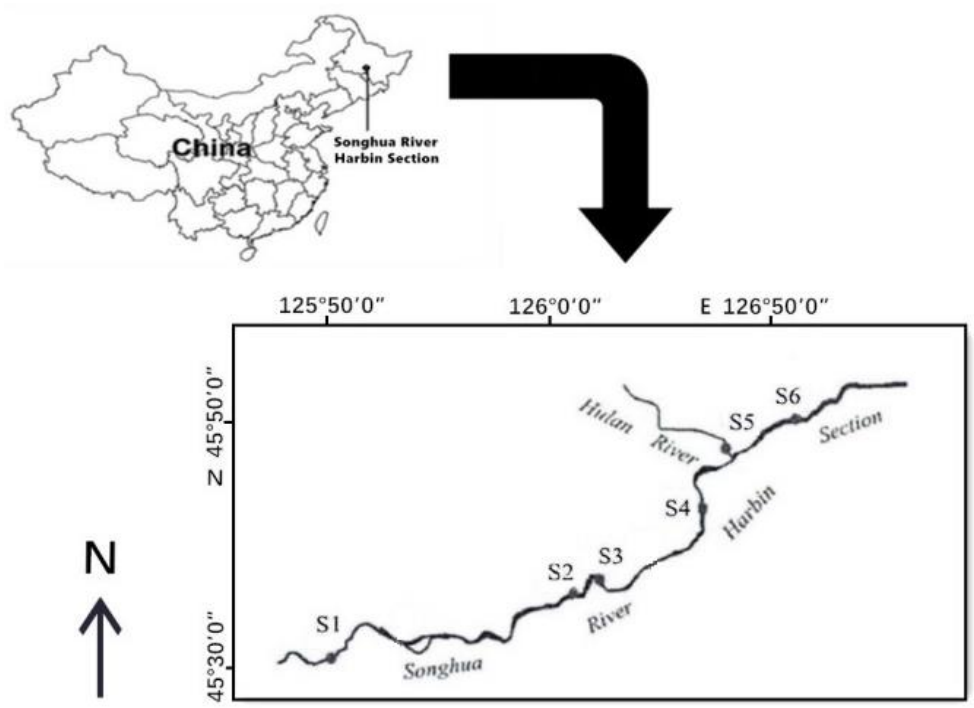

Figure 1. Distribution map of sampling sites (S1-S6) in the Harbin section of the Songhua River, China

Table 1. Six sampling site coordinates in the Harbin section of the Songhua River, China

\begin{tabular}{|c|c|c|}
\hline Sampling sites & Latitude & Longitude \\
\hline $\mathrm{S} 1$ & $\mathrm{~N} 45^{\circ} 32^{\prime} 21^{\prime \prime}$ & E125 $53^{\circ} " 12$ \\
\hline S2 & $\mathrm{N} 45^{\circ} 46^{\prime} 22^{\prime \prime}$ & $\mathrm{E} 126^{\circ} 29^{\prime} 32^{\prime \prime}$ \\
\hline S3 & $\mathrm{N} 45^{\circ} 45^{\prime} 20^{\prime \prime}$ & 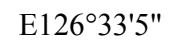 \\
\hline S4 & $\mathrm{N} 45^{\circ} 51^{\prime} 35^{\prime \prime}$ & 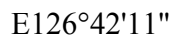 \\
\hline S5 & $\mathrm{N} 45^{\circ} 55^{\prime} 31^{\prime \prime}$ & E126 $46^{\prime} 31^{\prime \prime}$ \\
\hline S6 & N455'ㄱ' & $\mathrm{E} 126^{\circ} 50^{\prime} 48^{\prime \prime}$ \\
\hline
\end{tabular}


The survey of zooplankton groups was carried out in 6 sampling sites in spring (April 20, 2012), summer (July 10, 2012) and autumn (October 10, 2012), respectively. Each sampling site was sampled once on both sides of the Songhua River. Affected by monsoon climate, the surface water of the river was covered by ice from the end of November to the beginning of next April. The sampling sites of S1 and S2 located in the upstream, S3 and S4 located in the midstream and S5 and S6 located in the downstream.

\section{Field sampling and analysis}

\section{Sampling collection and analysis}

Water temperature (WT) was measured on field using water thermometer (Mercuryin-glass thermometer, Dezhou Runxin Experimental Instrument Co. LTD, China). PH, chemical oxygen demand (CODcr), permanganate index $\left(\mathrm{COD}_{\mathrm{Mn}}\right)$, biological oxygen demand $\left(\mathrm{BOD}_{5}\right)$, total nitrogen (TN), total phosphorus (TP), dissolved oxygen (DO), ammonia-nitrogen $\left(\mathrm{NH}_{4}{ }^{+}-\mathrm{N}\right)$, nitrate $\left(\mathrm{NO}^{3-}\right)$ and ferric ion $\left(\mathrm{Fe}^{3+}\right)$ were determined using the standard methods on surface water (GB/T5750-2006) of the Chinese standard methods proposed by Ministry of Environmental Protection of People's Republic of China (MEP, 2006). We used a zooplankton net of $25 \mathrm{~cm}$ diameter on boat, $55 \mathrm{~cm}$ length and $65 \mu \mathrm{m}$ mesh to zooplankton samples from subsurface $(0.5-1 \mathrm{~m}$ depth) when flow velocity was under the range of $0.01-2.40 \mathrm{~m} / \mathrm{s}$, and then fixed in labelled bottles of $30 \mathrm{ml}$ for further analysis. In the laboratory, zooplankton samples were identified using a microscope at 400×magnification (Motic BA210, Motic Inc., China). In this study, we considered copepod nauplii as a taxon (Wang, 1961; Crustacean Research Group, 1979; Jiang and Du, 1979; Han and Shu, 1995). The biomass of the zooplankton functional groups was evaluated using wet weight method of Zhang and Huang (1991).

\section{Classification of zooplankton functional group}

According to the researchers, the basic principle for classification of zooplankton functional groups is their size. The sampled zooplankton species in the Songhua River were classified into six functional groups according to their body size/length and mode of feeding (Zhao, 2005; Benedetti et al., 2018). The six functional groups are group PF (protozoa filter feeders), group PC (protozoa carnivore), group RF (rotifer filter feeders), group RC (rotifer carnivore), group SCF (small copepods and cladocerans filter feeders) and group MCF (middle copepods and cladocerans filter feeders). Group $\mathrm{PF}$ and RF are passive filter feeders feeding on phytoplankton, bacteria and organic detritus. Group RC and PC are active ambush feeders that target small motile prey or other zooplanktons. Functional group SCF consists of small copepods and cladocerans of body size less than $0.7 \mathrm{~mm}$ that mostly feed through filter-feeding on phytoplankton, bacteria, organic detritus and protozoa. Functional group MCF consists of those zooplankton species with body size in the range of 0.7-1.5 mm. MCF, is a filter-feeder feeding on phytoplankton, bacteria, organic detritus and protozoa, same as group SCF. Ecologically, MCF plays a major role as a food source for fish and also can control algal blooms (Meerhoff et al., 2007).

\section{Data analysis}

One-way analysis of variance (ANOVA), and Tukey's honestly were used in IBM SPSS STATISTICS 19.0 to determine significant difference between the seasonal changes of water environmental variables and zooplankton functional groups biomass 
(Sharma et al., 2017). Water environmental factors (except $\mathrm{pH}$ ) and biomass of zooplankton functional groups used $\log (\mathrm{x}+1)$ transformation before conducting analysis in order to satisfy the normality and variance assumption. Relationship between the biomass of zooplankton functional groups and environmental factors was computed using CANOCO 4.5 software (Shen et al., 2014). We used Detrended Correspondence Analysis (DCA) before multivariate ordination analysis. This result of DCA showed that the largest gradient length of the axis was 1.584 less than 3 . So the species data was linearly distributed and were more suitable for Redundancy analysis (RDA).

\section{Results}

\section{Seasonal variations in environmental factors}

The mean values of seasonal environmental variables recorded at the 6 sampling sites in the Harbin section of the Songhua River were presented in Table 2 and Fig. 2. Most of the environmental factors presented statistical differences between seasons (One-way ANOVA and Tukey HSD test, $\mathrm{P}<0.05$ ). However, the mean values of $\mathrm{COD}_{\mathrm{Mn}}, \mathrm{NH}_{4}{ }^{+}-\mathrm{N}$ and $\mathrm{TN}$ did not vary significantly between seasons $(\mathrm{P}>0.05)$. While WT, pH, DO, $\mathrm{COD}_{\mathrm{Cr}}, \mathrm{BOD}_{5}, \mathrm{TP}, \mathrm{N}: \mathrm{P}, \mathrm{NO}^{3-}$ and $\mathrm{Fe}^{3+}$, were significantly different with seasonal variations $(\mathrm{P}<0.05)$. The maximum mean values of $\mathrm{WT}, \mathrm{COD} \mathrm{Cr}, \mathrm{TP}, \mathrm{NO}^{3-}$ and $\mathrm{Fe}^{3+}$ were observed in summer and their minimum mean values were observed in autumn, except TP and $\mathrm{Fe}^{3+}$. On the contrary, the minimum mean values of $\mathrm{pH}, \mathrm{DO}$ and $\mathrm{BOD}_{5}$, were observed in summer and their maximum in spring, except DO. Unlike other significantly seasonal variations, the maximum mean value of $\mathrm{N}: \mathrm{P}$ was observed in spring and its minimum mean value was observed in autumn.

Table 2. One-way ANOVA and Tukey HSD methods were used to detect that the mean value ( \pm standard error) of environmental factors varies with seasonal changes in this chart

\begin{tabular}{c|c|c|c|c}
\hline & Spring & Summer & Autumn & P-value \\
\hline $\mathrm{WT}\left({ }^{\circ} \mathrm{C}\right)$ & $20.33 \pm 1.51 \mathrm{a}$ & $26.83 \pm 0.98 \mathrm{~b}$ & $11.5 \pm 0.84 \mathrm{c}$ & 0.000 \\
$\mathrm{pH}$ & $8.66 \pm 0.46 \mathrm{a}$ & $7.62 \pm 0.15 \mathrm{~b}$ & $8.02 \pm 0.15 \mathrm{~b}$ & 0.000 \\
$\mathrm{DO}(\mathrm{mg} / \mathrm{L})$ & $8.67 \pm 2.56 \mathrm{a}$ & $5.50 \pm 1.33 \mathrm{~b}$ & $10.13 \pm 0.27 \mathrm{a}$ & 0.001 \\
$\mathrm{COD}_{\mathrm{Mn}}(\mathrm{mg} / \mathrm{L})$ & $6.60 \pm 1.81 \mathrm{a}$ & $7.21 \pm 0.49 \mathrm{a}$ & $5.49 \pm 0.99 \mathrm{a}$ & 0.078 \\
$\mathrm{COD}_{\mathrm{Cr}}(\mathrm{mg} / \mathrm{L})$ & $21.67 \pm 5.5 \mathrm{a}$ & $98.83 \pm 5.12 \mathrm{~b}$ & $14.00 \pm 1.79 \mathrm{c}$ & 0.000 \\
$\mathrm{BOD}_{5}(\mathrm{mg} / \mathrm{L})$ & $5.67 \pm 1.57 \mathrm{a}$ & $1.93 \pm 1.6 \mathrm{~b}$ & $2.10 \pm 0.52 \mathrm{~b}$ & 0.000 \\
$\mathrm{NH}_{4}{ }^{+} \mathrm{N}(\mathrm{mg} / \mathrm{L})$ & $0.36 \pm 0.31 \mathrm{a}$ & $0.53 \pm 0.31 \mathrm{a}$ & $0.23 \pm 0.16 \mathrm{a}$ & 0.187 \\
$\mathrm{TP}(\mathrm{mg} / \mathrm{L})$ & $0.06 \pm 0.02 \mathrm{a}$ & $0.15 \pm 0.02 \mathrm{~b}$ & $0.14 \pm 0.05 \mathrm{~b}$ & 0.001 \\
$\mathrm{TN}(\mathrm{mg} / \mathrm{L})$ & $1.45 \pm 0.27 \mathrm{a}$ & $1.93 \pm 0.41 \mathrm{a}$ & $1.58 \pm 0.42 \mathrm{a}$ & 0.102 \\
$\mathrm{~N}: \mathrm{P}$ & $27.94 \pm 10.41 \mathrm{a}$ & $13.04 \pm 2.49 \mathrm{~b}$ & $12.32 \pm 2.8 \mathrm{~b}$ & 0.001 \\
$\mathrm{NO}^{3-}(\mathrm{mg} / \mathrm{L})$ & $0.96 \pm 0.46 \mathrm{a}$ & $2.61 \pm 0.22 \mathrm{~b}$ & $0.84 \pm 0.09 \mathrm{a}$ & 0.000 \\
$\mathrm{Fe}^{3+}(\mathrm{mg} / \mathrm{L})$ & $0.32 \pm 0.15 \mathrm{a}$ & $2.71 \pm 1.38 \mathrm{~b}$ & $0.78 \pm 0.46 \mathrm{a}$ & 0.000 \\
\hline
\end{tabular}

$\mathrm{P}$ value was a reference for determining test result using the method of One-way ANOVA. Environmental factors include: water temperature (WT), $\mathrm{pH}$, dissolved oxygen (DO), potassium permanganate index $\left(\mathrm{COD}_{\mathrm{Mn}}\right), 5$ days biochemical oxygen demand $\left(\mathrm{BOD}_{5}\right)$, chemical oxygen demand $\left(\mathrm{COD}_{\mathrm{Cr}}\right)$, ammonia nitrogen $\left(\mathrm{NH}_{4}^{+}-N\right)$, total phosphorus $(\mathrm{TP})$, total nitrogen $(\mathrm{TN}), \mathrm{N}$ : $\mathrm{P}$ ratio $(\mathrm{N}: \mathrm{P})$, nitrate $\left(\mathrm{NO}^{3-}\right)$ and dissolved iron $\left(\mathrm{Fe}^{3+}\right)$. By Tukey HSD ANOVA method, the mean value in each row with letters of $\mathrm{a}, \mathrm{b}$ and $\mathrm{c}$ reflected the difference of seasons 

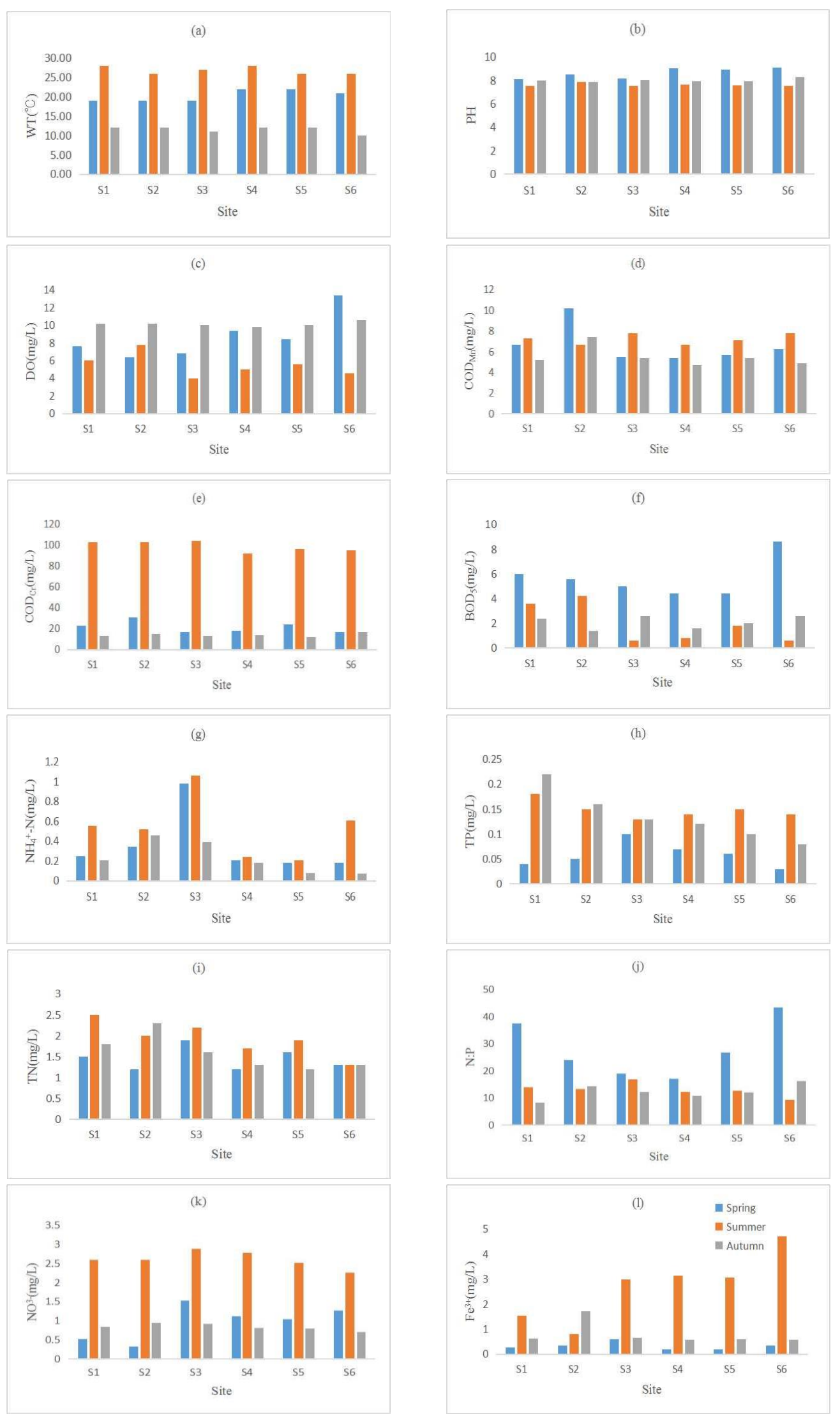

Figure 2. Spatial variations of selected environmental variables of the different seasons in the Harbin section of the Songhua River, China 


\section{Seasonal and spatial variation of zooplankton functional groups}

During the study period, 26 zooplankton species belonging to 20 genera were observed in spring, summer and autumn in 2012 in the Harbin section of the Songhua River, China (Table 3), where rotifers were composed of 17 species accounted about $65.38 \%$, followed by protozoans with $6(23.08 \%)$, cladocerans $2(7.69 \%)$ and copepods $1(3.85 \%)$. There were seasonal and spatial variation in biomass of zooplankton functional groups (Figs. 3 and 4). Our results showed that the largest number of zooplankton species was 17 in autumn, followed by 15 in spring and 14 in summer. The values of zooplankton functional group biomass were higher in spring at $0.48 \mathrm{mg} / \mathrm{L}$, followed by $0.42 \mathrm{mg} / \mathrm{L}$ in autumn and $0.17 \mathrm{mg} / \mathrm{L}$ in summer. In spring and summer, RF functional group had the highest biomass contribution of about $41.10 \%$ and $49.52 \%$, respectively. In autumn, approximately $62.58 \%$ of the total biomass contribution was of PF (Fig. 3). MCF was the second most contributors of the total biomass in summer, even if it was only collected in summer. The total biomass contribution of the PC was about $4.31 \%$, and no PC was collected in spring and summer. Spatially, with exception of sampling sites S1 and S6 were dominated by SCF, all the sampling sites were dominated by group RF in spring. In summer, groups PF, RF and RC were presented in almost all sampling sites. However, MCF, only present in S2 and S3, and were dominated in S2 and S3. Group PF in all the sampling sites were dominated in autumn.

Table 3. Zooplankton listed by functional groups and their biomass percentage ratio in the Harbin section of the Songhua River (*) present

\begin{tabular}{|c|c|c|c|c|c|c|}
\hline $\begin{array}{l}\text { Taxonomic } \\
\text { group }\end{array}$ & Species & $\begin{array}{c}\text { Functional } \\
\text { groups }\end{array}$ & Spring & Summer & Autumn & $\begin{array}{c}\text { Percentage of } \\
\text { total } \\
\text { biomass }(\%)\end{array}$ \\
\hline \multirow[t]{6}{*}{ Protozoa } & Difflugia acuminata & $\mathrm{PF}$ & & $*$ & & 0.42 \\
\hline & Strobilidium velox & $\mathrm{PF}$ & $*$ & * & $*$ & 3.77 \\
\hline & Strombidium viride & $\mathrm{PF}$ & $*$ & & $*$ & 13.82 \\
\hline & Tintinnopsis wangi & $\mathrm{PF}$ & $*$ & $*$ & $*$ & 2.51 \\
\hline & Vorticella microstoma & $\mathrm{PF}$ & $*$ & $*$ & $*$ & 14.07 \\
\hline & Askenasia volvox & $\mathrm{PC}$ & & & * & 1.67 \\
\hline \multirow[t]{17}{*}{ Rotifera } & Brachionus angularis & $\mathrm{RF}$ & $*$ & & $*$ & 1.51 \\
\hline & Brachionus quadridentatus & $\mathrm{RF}$ & $*$ & $*$ & $*$ & 25.47 \\
\hline & Brachionus urceus & $\mathrm{RF}$ & $*$ & & & 0.07 \\
\hline & Filinia longiseta & $\mathrm{RF}$ & $*$ & & $*$ & 0.40 \\
\hline & Filinia maior & $\mathrm{RF}$ & & $*$ & & 0.04 \\
\hline & Gastropus hyptopus & $\mathrm{RF}$ & & $*$ & & 0.02 \\
\hline & Keratella cochlearis & RF & $*$ & $*$ & $*$ & 0.23 \\
\hline & Keratella quadrata & $\mathrm{RF}$ & $*$ & & & 0.38 \\
\hline & Keratella valga & $\mathrm{RF}$ & & $*$ & $*$ & 0.08 \\
\hline & Lecane ludwigii & $\mathrm{RF}$ & $*$ & & & 0.02 \\
\hline & Lecane luna & $\mathrm{RF}$ & & $*$ & & 0.01 \\
\hline & Monostyla quadridentata & $\mathrm{RF}$ & & & $*$ & 0.01 \\
\hline & Ploesoma hudsoni & $\mathrm{RF}$ & & $*$ & & 6.98 \\
\hline & Trichotria tetractis & $\mathrm{RF}$ & & & $*$ & 0.01 \\
\hline & Polyarthra trigla & $\mathrm{RC}$ & $*$ & $*$ & $*$ & 13.51 \\
\hline & Synchaeta stylata & $\mathrm{RC}$ & $*$ & & * & 0.27 \\
\hline & Trichocerca lophoessa & $\mathrm{RC}$ & & $*$ & $*$ & 0.07 \\
\hline \multirow[t]{2}{*}{ Cladoceran } & Diaphanosoma sp & $\mathrm{MCF}$ & & $*$ & & 4.19 \\
\hline & Bosmina sp & $\mathrm{SCF}$ & $*$ & & $*$ & 4.19 \\
\hline Copepoda & microcyclops javanus & SCF & $*$ & & * & 6.28 \\
\hline
\end{tabular}

Protozoa filter feeders (PF), protozoa carnivore (PC), rotifera filter feeders (RF), rotifer carnivore (RC), small copepods and cladocerans filter feeders (SCF) and middle copepods and cladocerans filter feeders (MCF) 


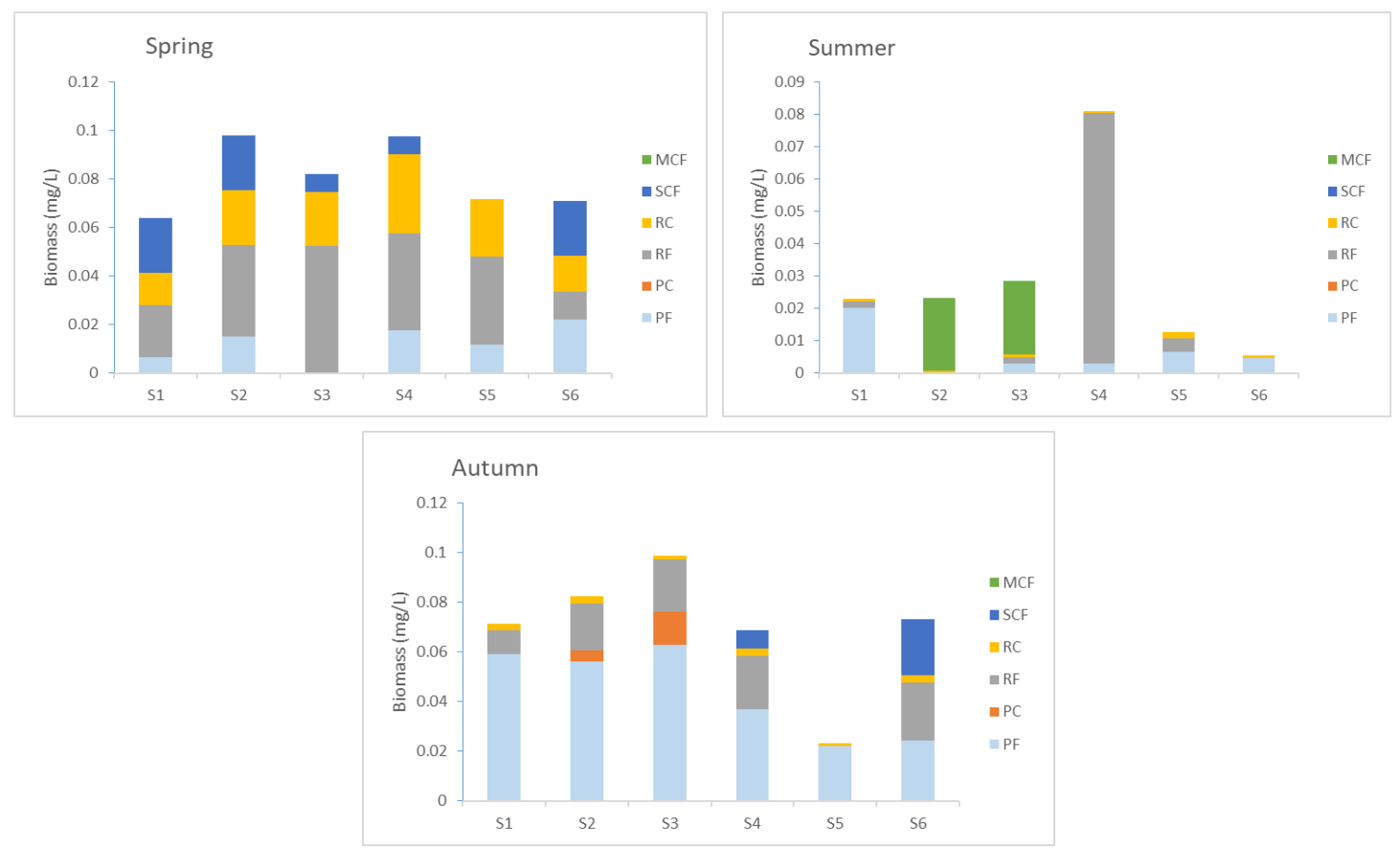

Figure 3. Distribution of zooplankton functional group biomass of spring, summer and autumn in the Harbin section of the Songhua River, China

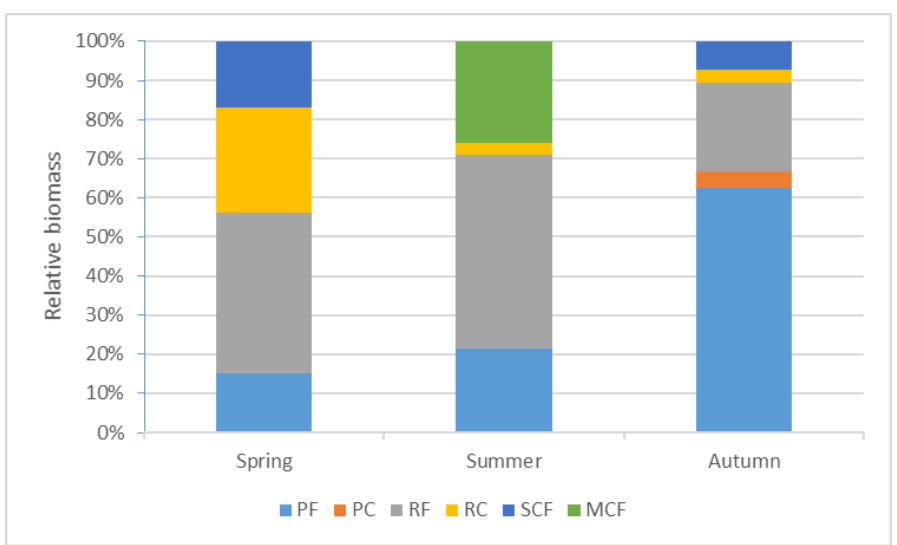

Figure 4. Seasonal variation of relative mean biomass of zooplankton functional groups in the Harbin section of the Songhua River, China

\section{Redundancy analysis (RDA) of zooplankton functional groups with environmental factors variables}

It was carried out to determine the relationship between the biomass of zooplankton functional groups and environmental factors variables in the RDA ordination in Table 4. The Monte Carlo test showed that the first axis and all typical axes were significant $($ F-ratio $=3.894, \mathrm{p}$-value $=0.0580 ; \mathrm{F}$-ratio $=3.974, \mathrm{p}$-value $=0.0040 ; 499$ random permutations under simplified model). The first two of RDA eigenvalue axes together explained $75.3 \%$ (axis 1: $43.8 \%$; axis $2: 31.5 \%$ ) zooplankton functional group biomass and $83.2 \%$ (axis 1: $48.4 \%$; axis 2: $34.8 \%$ ) relationship of the zooplankton functional group biomass and environmental factors. The relationship between zooplankton 
functional groups and environmental factors can be referred to arrow directions in Fig. 5. Axis 1 was mainly positive correlated with $\mathrm{WT}(\mathrm{r}=0.4939)$ and $\mathrm{NH}_{4}{ }^{+}-\mathrm{N}$ $(\mathrm{r}=0.4442)$ and negatively related with TP $(\mathrm{r}=-0.3256)$. While Axis 2 was mainly positive correlated with WT $(\mathrm{r}=0.7158)$ and $\mathrm{COD}_{\mathrm{Cr}}(\mathrm{r}=0.7097)$ and negatively related with DO $(\mathrm{r}=-0.4201)$. Groups of PF and PC were positively related with DO, and negatively correlated with WT, COD $\mathrm{Mn}, \mathrm{COD}_{\mathrm{Cr}}$ and $\mathrm{NO}^{3-}$. Groups of RF, RC and SCF were positively correlated with $\mathrm{pH}, \mathrm{N}: \mathrm{P}$ and $\mathrm{BOD}_{5}$, and negatively related with $\mathrm{Fe}^{3+}$ and TP. Conversely, Group MCF were positively correlated with $\mathrm{Fe}^{3+}$ and negatively correlated with $\mathrm{pH}$.

Table 4. Redundancy analysis (RDA) results of zooplankton functional groups in the Harbin section of the Songhua River, China

\begin{tabular}{c|c|c|c|c}
\hline & Eigenvalues & $\begin{array}{c}\text { Species-environment } \\
\text { correlations }\end{array}$ & $\begin{array}{c}\text { Cumulative percentage } \\
\text { variance of species data }\end{array}$ & $\begin{array}{c}\text { Cumulative percentage } \\
\text { variance of species- } \\
\text { environment relation }\end{array}$ \\
\hline Axes 1 & 0.438 & 0.960 & 43.8 & 48.4 \\
Axes 2 & 0.316 & 0.961 & 75.3 & 83.2 \\
Axes 3 & 0.088 & 0.923 & 84.1 & 92.9 \\
Axes 4 & 0.038 & 0.914 & 87.9 & 97.1 \\
$\begin{array}{c}\text { Sum of all canonical } \\
\text { eigenvalues }\end{array}$ & 0.905 & & & \\
\hline
\end{tabular}

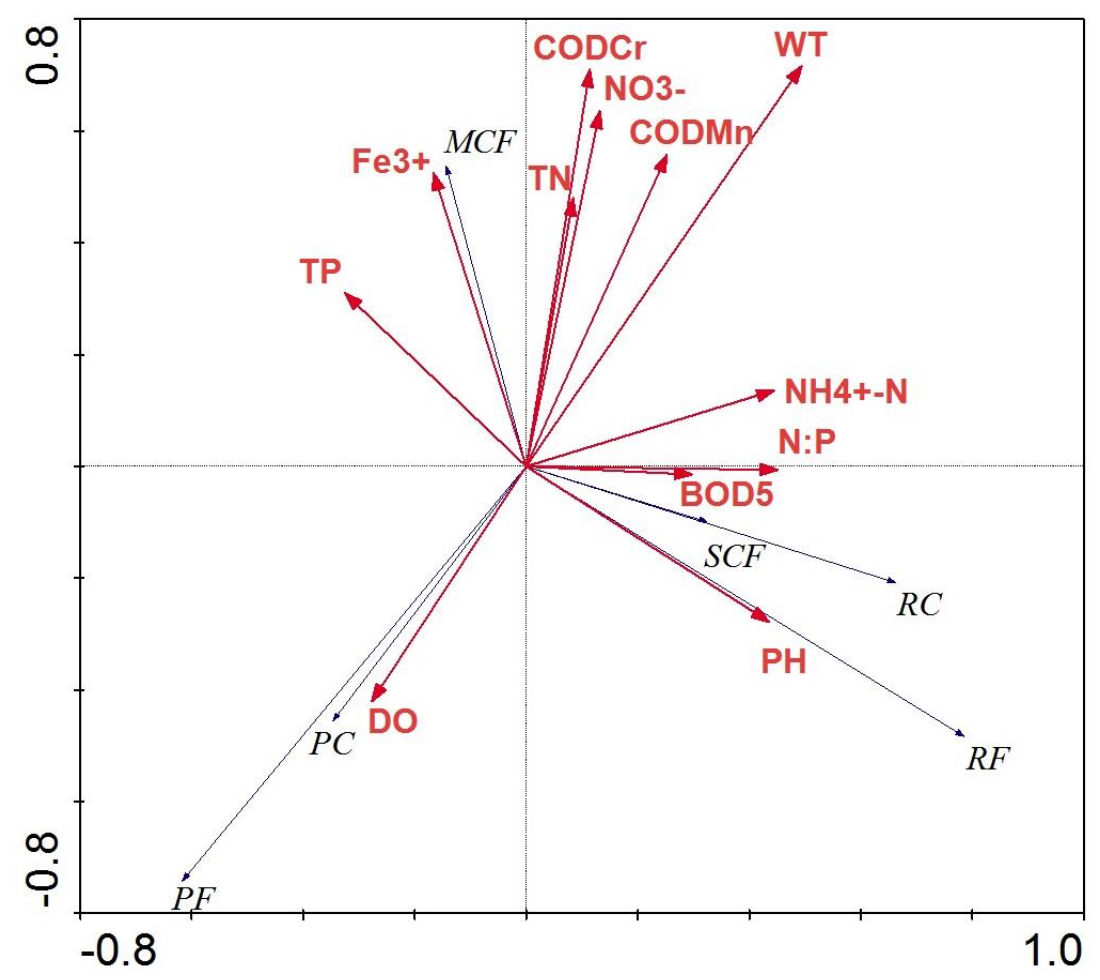

Figure 5. Biological ordination diagram of Redundancy analysis (RDA) of zooplankton functional groups (blue lines with black letters) and environmental factor variables (red lines with red letters) in the Harbin section of the Songhua River, China 


\section{Discussion}

\section{Seasonal variation of zooplankton functional groups biomass}

Biomass is one of the most important variables to describe the spatial and temporal variation of zooplankton functional groups in aquatic ecosystems (Shi et al., 2015), which can reduce the disturbance of simulated ecosystem caused by large differences in zooplankton. The present study provided novel insights into the seasonal changes of the zooplankton biomass in the Harbin section of the Songhua River, China. Comparison with other waters of regions showed that the zooplankton biomass in the Harbin section of the Songhua River was significantly lower. In the recently published literature, the zooplankton biomass of Tuanjie Reservoir in Mudanjiang city (Sun et al., 2019) and Small Xingkai Wetland in Jixi City (Ma et al., 2019) showed were higher than thoese in the same province of the Songhua River in each quarter. The result of Shi et al. (2016) showed that the rivers with high velocity and sediment content were not suitable for the habitat and reproduction of zooplankton (Fang et al., 2012). The study of Mwagona et al. (2018) had also shown that zooplankton growth was affected when their nutrient levels were low, reducing their reproductive rate and prolonging their growth cycles. In this study, the biomass of zooplankton functional groups had significant differences between different seasons. Differences in functional groups and life history traits of the dominant species have to be taken into account to explain these seasonal biomass patterns. In spring and summer, the biomass of zooplankton was mainly RF, of which $86.79 \%$ was composed of Brachionus quadridentatus and $87.29 \%$ was composed of ploesoma hudsoni. In autumn, PF was dominant, mainly composed of Strombidium viride and Vorticella microstoma, which accounted about $46.50 \%$ and $46.61 \%$ of the total biomass, respectively. Studies have found a strong positive correlation between rotifer biomass and temperature (Galkovskaja, 1987). Therefore, when the water temperature turned cold, the RF who fed on bacteria, phytoplankton and organic matter gets less, and the PF which also fed on these things got less grazing pressure and became the dominant specie due to the decrease of RF. In spatial distribution, seasonal dominant functional groups changed most obviously in the sampling sites of S2 and S3: $\mathrm{RF} \rightarrow \mathrm{MCF} \rightarrow \mathrm{PF}$. Summer temperature and nutrients provided the best conditions for MCF to be the dominant functional group. These factors greatly enrich the source of food resources for MCF. MCF which fed on bacteria, phytoplankton and organics inhibits the growth of RF by predation (An, 2016).

\section{The driving factors of zooplankton functional groups in the Harbin section of Songhua Rive, China}

The interaction between zooplankton functional groups and its relationship with water environmental factors, such as temperature, nutrients, bottom-up effect of phytoplankton, top-down effect of fish feeding, interspecies competition, were the main factors affecting the growth of zooplankton (Yang, 2006). At the same time, these physiological processes of zooplankton function groups showed a highly sensitive response to changes in the environment, and zooplankton function groups can amplify subtle changes in water environment and made it a very good indicator for freshwater ecosystems (Richardson, 2008). In temperate regions, water temperature and nutrients were the main environmental factors (Wen and Xie, 2013). In this study, RDA results indicated that water temperature was the main factor affecting zooplankton. The big difference in temperature of the Songhua River water along the year round considered 
as a controlling factor related to range of tolerance of species. From the result of RDA, some function groups reacted positively to water temperature as group MCF, contrary to groups of PC and PF. We believe that the reproduction of these groups is related to temperature preference. Related researches showed that higher water temperature can promote the metabolism of zooplankton in the meanwhile they also increase the consumption of nutrients and proteins, and body mortality (Zheng, 1992). Brachionus quadridentatus quickly produced resting eggs at higher or lower temperatures (Xiang et al., 2018). However, MCF, which was composed of Diaphanosoma, was positively correlated with water temperature. Experiments had shown that Diaphanosoma often appeared in summer and prefer to live in warm water environment (Brendonck and Meester, 2003). The growth rate of Diaphanosoma was accelerated when water temperature rose, and the growth rate of Diaphanosoma was slower when water temperature was lower. In addition, RDA analysis indicated that group PF was positively related with $\mathrm{DO}$ and negatively related with $\mathrm{NH}_{4}{ }^{+}-\mathrm{N}$ and $\mathrm{COD}_{\mathrm{Cr}}$, and groups of RC and SCF were negatively correlated with TP. Similarly, with the research of Shen (1999) confirming that most protozoans were aerobic biological. The diversity of protozoans in the abundant water environment would be higher than that of the anaerobic environment. Lu et al. (2007) in the study of wastewater found that, although Vorticella microstoma was the indicator species of mesosaprobic zone. When increasing the DO in aeration activated sludge, the density of Vorticella microstoma in activated sludge was significantly higher than the control group. In the study of protozoans, it was found that the sessile ciliates diversity index (such as Epistylisplicatilis, Vorticella convallaria, Pseudocarchesium aselli and Opercularia cylindrata) and crawling ciliates (Aspidisca costata and Aspidisca sulcate) were negatively correlated with $\mathrm{NH}_{4}{ }^{+}-\mathrm{N}$ (Chen et al., 2003). In the study of zooplankton in Small Xingkai Lake Wetlands, it was found that $\mathrm{COD}$ was the main negative correlation factors affecting the functional groups of zooplankton (An, 2016). The author thought that the pollutants mainly came from agricultural wastewater around the river, which were directly affected the bottomup effects of phytoplankton and indirectly affected the growth rate of zooplankton. In the study of Zhao and Yu (2019) of on zooplankton functional groups in Tai Lake, RDA results showed that zooplankton was positively related with $\mathrm{COD}_{\mathrm{Cr}}$. The results of $\mathrm{Ma}$ et al. (2019) revealed that TP were the main factors responsible of zooplankton functional groups biomass dynamics. The results of Meng et al. (2014) found that chlorophyta grew in phosphorus-restricted environments made thicker cell wall to makes less edible. The research of Siebielec et al. (2015), da Silva Cerozi and Fitzsimmons (2016) clearly proved that dissolved calcium ion should react with the phosphate in water forming insoluble calcium phosphate and other compounds that were not conducive to phytoplankton growth and propagation when the water environment was slight alkaline. In fact, Marzolf (1990) and Adamczuk et al. (2015) thought phytoplankton itself didn't meet all of the nutritional requirements of zooplankton. It further confirms that filter feeders of the protozoas and rotifera provided an important food supplement to carnivore functional groups under the condition of limited amounts of bacterial phytoplankton. So we should be undertaken to follow the changes in the ecosystem continuous monitoring of water characteristics and biota in the Harbin section of the Songhua River, China. 


\section{Conclusions}

In this current study, a total of 26 species of zooplankton species were observed in 2012 in the Harbin section of the Songhua River, China. Zooplankton was divided into 6 functional groups: protozoa filter feeders (PF), protozoa carnivore (PC), rotifer filter feeders (RF), rotifer carnivore (RC), small copepods and cladocerans filter feeders (SCF) and middle copepods and cladocerans filter feeders (MCF). The biomass of zooplankton functional groups ranged from large to small in spring, autumn, and summer. One-way ANOVA and Redundancy analysis (RDA) showed that the environmental parameters as water temperature (WT), $\mathrm{pH}$, dissolved oxygen (DO), chemical oxygen demand ( $\left.\mathrm{COD}_{\mathrm{cr}}\right), 5$ days biochemical oxygen demand ( $\left.\mathrm{BOD}_{5}\right)$, total phosphorus (TP), $\mathrm{N}$ : $\mathrm{P}$ ratio $(\mathrm{N}: \mathrm{P})$, nitrate $\left(\mathrm{NO}^{3-}\right)$ and dissolved iron $\left(\mathrm{Fe}^{3+}\right)$ influenced on the change of the biomass of zooplankton functional groups. Groups of PF and PC had strong relationships with dissolved oxygen (DO), water temperature (WT) and chemical oxygen demand $\left(\mathrm{COD}_{\mathrm{cr}}\right)$ of environmental parameters. Groups of RF, RC and SCF had strong relationships with $\mathrm{pH}$ and total phosphorus (TP). Group MCF had strong relationships with dissolved iron $\left(\mathrm{Fe}^{3+}\right)$ and total phosphorus (TP). This study revealed that the zooplankton functional groups followed certain predictable pattern in the seasonal gradient. It could be useful for assessing and predicting the growth and development of zooplankton in the future. At present, functional-approach research studies for zooplankton communities in continental aquatic environments are scarce. Therefore, the scientific community must take into account the environmental and spatial dynamics of these organisms and conduct more research on the traits related to their different ecological functions.

\section{REFERENCES}

[1] Adamczuk, M., Mieczan, T., Nawrot, D., Rechulicz, J. (2015): Indirect effect of environmental factors on interactions between microbial and classical food webs in freshwater ecosystems. - Ann Limnol.-Int J Lim 51(1): 49-58.

[2] An, R. (2016): Characteristics and environmental effect of plankton functional groups in Sanjiang Plate wetland. - Northeast Forestry University, Harbin.

[3] Bao, W. M., Wang, Q. X., Shi, X. L. (1989): Studies on the Phytoplankton in the Gaoleng-Yilan Section of the Songhua River, An Evaluation on the Status of the Quality of the Polluted Water in that Section. - Natural Sciences Journal of Harbin normal university 5: 75-93.

[4] Benedetti, F., Vogt, M., Righetti, D., Guilhaumon, F., Ayata, S. D. (2018): Do functional groups of planktonic copepods differ in their ecological niches? - J Biogeogr 45: 604616.

[5] Brendonck, L., Meester, L. D. (2003): Egg banks in freshwater zooplankton: evolutionary and ecological archives in the sediment. - Hydrobiologia 491: 65-84.

[6] Chen, S. G., Xu, M. Q., Cao, H., Zhou, K. X., Xu, J., Yang, X. P., Gan, Y. P., Zhai, J. Y., Liu, W. Y., Shao, Y. Y. (2003): Relationship between the dynamics of mixed liquor fauna and the efficiency of wastewater purification. - Acta Zoologica Sinica 49: 775-786.

[7] Cianciaruso, M. V., Silva, I. A., Batalha, M. A. (2009): Diversidades filogenetica e funcional: novas abordagens para a Ecologia de comunidades. - Biota Neotrop 9: 93-103. https://doi.org/10.1590/S1676-06032009000300008.

[8] Crustacean Research Group, Institute of Zoology, Chinese Academy of Sciences. (1979): China Fauna, Arthropoda, Crustacea, Freshwater Copepoda. -China zoology editorial board, Chinese academy of sciences, Science Press, Beijing. 
[9] da Silva Cerozi, B., Fitzsimmons, K. (2016): The effect of pH on phosphorus availability and speciation in an aquaponics nutrient solution. - Bioresour Technol 219: 778-781.

[10] Fang, Y. H., Huang, D. H., Wang, W. J., Zhao, S. S., Jian, D., Xie, S., Zhang, Q. (2012): Characteristics of Community Structure of Zooplankter in Autumn at Estuary of Dadu River. - Journal of Hydroecology 33: 34-39.

[11] Galkovskaja, G. (1987): Planktonic rotifers and temperature. - Hydrobiologia 147: 307317.

[12] Gianuca, A. T., Engelen, J., Brans, K. I., Hanashiro, F. T. T., Vanhamel, M., van den Berg, E. M., Souffreau, C., De Meester, L. (2018): Taxonomic, functional and phylogenetic metacommunity ecology of cladoceran zooplankton along urbanization gradients. - Ecography 41(1): 183-194. https://doi.org/10.1111/ecog.02926.

[13] Han, M. S., Shu, Y. F. (1995): Chinese Freshwater Biology Atlas. - Ocean Press, Beijing, pp. 156-296.

[14] Hoeinghaus, D. J., Winemiller, K. O., Birnbaum, J. S. (2007): Local and regional determinants of stream fish assemblage structure: inferences based on taxonomic vs. functional groups. - J. Biogeogr 34: 324-338.

[15] Hood, R. R., Laws, E. A., Armstrong, R. A., Bates, N. R., Brown, C. W., Carlson, C. A., Chai, F., Doney, S. C., Falkowski, P. G., Feely, R. A., Friedrichs, M. A. M., Landry, M. R., Moore, J. K., Nelson, D. M., Richardson, T. L., Salihoglu, B., Schartau, M., Toole, D. A., Wiggert, J. D. (2006): Pelagic functional group modeling: progress, challenges and prospects. - Deep Sea Research Part II: Topical Studies in Oceanography 53: 459-512.

[16] Jiang, X. Z., Du, N. S. (1979): China Fauna, Arthropoda, Crustacea, Freshwater Cladocera. - Science Press, Beijing, pp. 80-271.

[17] Le Quéré, C., Harrison, S. P., Prentice, I. C., Bultenhuis, E. T., Aumont, O., Bopp, L., Claustre, H., Cunha, L. C. D., Geider, R., Giraud, X., Klaas, C., Kohfeld, K. E., Legendre, L., Manizza, M., Platt, T., Rivkin, R. B., Sathyendranath, S., Uitz, J., Watson, A. J., Wolf-Gladrow, D. (2005): Ecosystem dynamics based on plankton functional types for global ocean biogeochemistry models. - Global Change Biology 11: 2016-2040.

[18] Leoni, B. (2016): Zooplankton predators and prey: body size and stable isotope to investigate the pelagic food web in a deep lake (Lake Iseo, Northern Italy). - University Milan Bicocca, Disat, Italy. https://doi.org/10.4081/jlimnol.2016.1490.

[19] Li, X. Y., Yu, H. X., Ma, C. X. (2014): Zooplankton community structure in relation to environmental factors and ecological assessment of water quality in the Harbin Section of the Songhua River. - Chinese Journal of Oceanology and Limnology 6: 1344-1351.

[20] Lira, A., Angelini, R., Le Loch, F., Menard, F., Lacerda, C., Fredou, T., Fredou, F. L. (2018): Trophic flow structure of a neotropical estuary in northeastern Brazil and the comparison of ecosystem model indicators of estuaries. - J Mar Syst 182: 31-45. https://doi.org/10.1016/j.jmarsys. 2018.02.007.

[21] Litchman, E., Ohman, M. D., Kiørboe, T. (2013): Trait-based approaches to zooplankton communities. - J Plankton Res 35: 473-484. https://doi.org/10.1093/plankt/fbt019.

[22] Lu, Y. Z., Ning, Y. Z., Ma, Z. X., Liu, J. F. (2007): Studies on community structure of ciliates from activated sludge in Yanerwan sewage plant in spring. - Journal of Northwest Normal University (Natural Science) 43: 72-76.

[23] Ma, C. X., Mwagona, P. C., Yu, H. X., Sun, X. W., Liang, L. Q. (2019): Seasonal dynamics of zooplankton functional group and its relationship with physicochemical variables in high turbid nutrient-rich Small Xingkai Wetland Lake, Northeast China. Journal of Freshwater Ecology 34: 65-79.

[24] Mano, H., Tanaka, Y. (2016): Mechanisms of compensatory dynamics in zooplankton and maintenance of food chain efficiency under toxicant stress. - Ecotoxicology 25: 399411. https://doi.org/10.1007/s10646-015-1598-2.

[25] Martiny, A. C., Treseder, K., Pusch, G. (2013): Phylogenetic conservatism of functional traits in microorganisms. - ISME J 7: 830-838. https://doi.org/10.1038/ismej.2012.160. 
[26] Marzolf, G. (1990): Reservoirs as environments for zooplankton, Reservoir Limnology: Ecological Perspectives. - John Wiley \& Sons, Inc., New York, pp. 195-208.

[27] Meerhoff, M., Iglesias, C., De Mello, F. T., Clemente, J. M., Jensen, E., Lauridsen, T. L., Jeppesen, E. (2007): Effects of habitat complexity on community structure and predator avoidance behaviour of littoral zooplankton in temperate versus subtropical shallow lakes. - Freshw Biol 52: 1009-1021.

[28] Meng, M. R., Deng, D. G., Zhang, X. L. (2014): The influence of phosphorus concentration on the population dynamics and resting egg formation of two cladocerans. - Journal of Freshwater Ecology 29: 387-396.

[29] Ministry of Environmental Protection, China [MEP] (2006): China's national standard: GB/T5750-2006: Environmental quality standards for surface water. - Ministry of Environmental Protection, China Standards Press. Beijing, China.

[30] Mwagona, P. C., Ma, C. X., Yu, H. X. (2018): Seasonal dynamics of Zooplankton functional groups in relation to environmental variables in Xiquanyan Reservoir, Northeast China. - Annales de Limnologie-International Journal of Limnology 54: 33.

[31] Obertegger, U., Manca, M. (2011): Response of rotifer functional groups to changing trophic state and crustacean community. - J Limnol 70: 231-238. https://doi.org/10.3274/JL11-70-2-07.

[32] Petchey, O. L., Gaston, K. J. (2002): Functional diversity (FD), species richness and community composition. - Ecol Lett 5: 402-411. https://doi.org/10.1046/j.14610248.2002.00339.x.

[33] Petchey, O. L., Gaston, K. J. (2006): Functional diversity: back to basics and looking forward. - Ecol Lett 9: 741-758. https://doi.org/10.1111/j.1461-0248.2006.00924.x.

[34] Pool, T. K., Grenouillet, G., Villéger, S. (2014): Species contribute differently to the taxonomic, functional, and phylogenetic alpha and beta diversity of freshwater fish communities. - Divers Distrib 20: 1235-1244. https://doi.org/10.1111/ddi.12231R Core Team (2017).

[35] Raevel, V., Violle, C., Munoz, F. (2012): Mechanisms of ecological succession: insights from plant functional strategies. - Oikos 121: 1761-1770. https://doi.org/10.1111/j.16000706. 2012.20261.x.

[36] Richardson, A. J. (2008): In hot water: zooplankton and climate change. - ICES J Mar Sci 65: 279-295.

[37] Rizo, E. Z. C., Gu, Y. L., Papa, R. D. S., Dumont, H. J., Han, B. P. (2017): Identifying functional groups and ecological roles of tropical and subtropical freshwater Cladocera in Asia. - Hydrobiologia 799: 83-99. https://doi.org/10.1007/s10750-017-3199-y.

[38] Sharma, A. S., Gupta, S., Singh, N. R. (2017): Zooplankton community of Keibul Lamjao National Park (KLNP) Manipur, India in relation to the physico-chemical variables of the water. - Chin J Oceanol Limnol 35: 469-480.

[39] Shen, Y. F. (1999): Protozoology. - Science Press, Beijing.

[40] Shen, H., Li, B., Cai, Q., Han, Q., Gu, Y., Qu, Y. (2014): Phytoplankton functional groups in a high spatial heterogeneity subtropical reservoir in China. - J Great Lakes Res 40: 859-869.

[41] Shi, Y. Q., Sun, S., Zhang, G. T., Wang, S. W., Li, C. L. (2015): Distribution pattern of zooplankton functional groups in the yellow sea in June: a possible cause for geo graphical separation of giant jellyfish species. - Hydrobiologia 754: 43-58.

[42] Shi, Y. Q., Sun, S., Li, C. L., Zhang, G. T. (2016): Interannual changes in the abundance of zooplankton functional groups in the southern yellow sea in early summer. Oceanologia Et Limnologia Sinica 1: 1-8.

[43] Siebielec, G., Ukalska-Jaruga, A., Kidd, P. (2015): Bioavailability of trace elements in soils amended with high-phosphate materials, Phosphate in Soils: Interaction with Micronutrients, Radionuclides Heavy Metals. - FL: CRC Press, Boca Raton, Vol. 2: 237260. 
[44] Songliao Water Resources Commission. (2012): Songliao River Sediment Bulletin: 4-5. Ministry of Water Resources.

[45] Sun, S., Huo, Y., Yang, B. (2010): Zooplankton functional groups on the continental shelf of the yellow sea, Deep Sea Research Part II. - Topical Studies in Oceanography 57: $10-16$.

[46] Sun, X., Chai, F. Y., Mwagona, P. C., Shabani, I. E., Hou, W. J., Li, X. Y., Ma, C. X., Pan, H. F., Li, S., Yu, H. X. (2019): Seasonal variations of. zooplankton functional groups and relationship with environmental factors in a eutrophic reservoir from cold region. - Applied Ecology and Environmental Research 17: 7727-7740.

[47] Tilman, D. (2001): Functional diversity. - In: Encyclopedia of biodiversity. Elsevier, pp. 587-596.

[48] Vieira, A. C. B., Medeiros, A. M. A., Ribeiro, L. L., Crispim, M. C. (2011): Population dynamics of Moina minuta Hansen (1899), Ceriodaphnia cornuta Sars (1886), and Diaphanosoma spinulosum Herbst (1967) (Crustacea: Branchiopoda) in different nutrients ( $\mathrm{N}$ and $\mathrm{P}$ ) concentration ranges. - Acta Limnol Bras 23: 48-56. https://doi.org/10.4322/actalb.2011.018.

[49] Wang, J. J. (1961): Rotifera Sinicarum Aquae Dulcis. - Science Press, Beijing: 21-282.

[50] Wei, N. (2018): Relationship between phytoplankton diversity and environment in the Harbin section of Songhua River. - Heilongjiang Environmental Journal 42: 86-91.

[51] Wen, Z. R., Xie, P. (2013): Seasonal Change of Water Quality and the Density of Crustacean Zooplankton in Meiliangand Gonghu Bays of Taihu Lake. - Journal of Yangtze University (Nat Sci Edit) 10: 36-51.

[52] Xiang, X. L., Zhu, L. Y., Chen, Y. Y., Wan, F. Y., Kang, L., Xi, Y. L. (2018): Combined effects of the microcystin MC-LR and temperature on the morphological features of Brachionus calyciflorus. - Journal of Lake Sciences 30: 1027-1040.

[53] Yang, Y. F., Wang, Q., Chen, J. F., Pang, S. X. (2006): Research advance in estuarine zooplankton ecology. - Acta Ecologica Sinica 26: 576-58.

[54] Zhang, Z. S., Huang, X. F. (1991): Research methods on freshwater plankton. - Science Press, Beijing: 358-362.

[55] Zhao, W. (2005): Hydrobiology. - Agricultural Press of China, Beijing.

[56] Zhao, Y. X., Yu, H. X. (2019): Structure and Environmental Impact Factors of Summer Zooplankton Functional Groups in Taihu Wetland. - Advances in Environmental Protection 9: 179-188.

[57] Zheng, Z. (1992): Biology of Marine copepods. - Xiamen University Publishing Company, Xiamen. 